\title{
Surface roughness in relation to altitude of hornbeam wood
}

\section{Rugosidad de la superficie de madera de Carpinus betulus con respecto a la altitud}

\author{
Majid Kiaej** and Rasoul Mosavi Paloj'
}

1 Department of Wood and Paper Science and Technology, Chalous Branch, Islamic Azad University, Chalous, Iran.
*Corresponding author. mjd_kia59@yahoo.com; mjdkia59@iauc.ac.ir

\begin{abstract}
Hornbeam wood (Carpinus betulus) is a native species from Iran and covers $33 \%$ of the commercial volume of Iranian woods. Surface quality of solid wood products is one of the most important properties influencing further manufacturing processes such as finishing or strength of adhesive joint. Wood surface roughness is affected by growth condition. The objective of this study was to evaluate effect of altitude index (400 m, $800 \mathrm{~m}$ and 1200 $\mathrm{m}$ ) on the surface roughness of sanded hornbeam wood (C. Betulus). Surface characteristics of sanded specimens of hornbeam wood were made employing a stylus profilmeter. Average roughness (Ra), mean peak-to-valley height ( $\mathrm{Rz})$, root-mean square deviation of the profile (Rq), core roughness depth $(\mathrm{Rk})$, reduced peak height (Rpk), and reduced valley depth (Rvk) roughness parameters were used to determine surface characteristics of the test pieces. Significant statistical differences were found among altitude indexes in reduced valley depth parameter and wood oven-dried density, but not for the other variables. This variable did not have significantly effect on other surface roughness parameters in hornbeam wood. The low altitude had a rougher surface than intermediate and high altitudes. There is no relationship between surface roughness parameter and wood oven-dried density.
\end{abstract}

KEYWORDS: growth condition, sanding, surface quality, sawn wood, wood density.

\section{RESUMEN}

La especie Carpinus betulus ('hornbeam') es una especie nativa de Irán y cubre 33\% del volumen comercial de las maderas de este país. La calidad de la superficie de productos de madera sólida de 'hornbeam' es una de sus propiedades más importantes, que afecta los procesos de manufactura tales como acabados o resistencia de las uniones con adhesivos. La rugosidad de la superficie de la madera se ve afectada por las condiciones de crecimiento del árbol. El objetivo de este estudio fue evaluar el efecto del índice de altitud ( $400 \mathrm{~m}, 800 \mathrm{~m}$ y $1200 \mathrm{~m}$ ) en la rugosidad de la superficie de madera de 'hornbeam' lijada. Las características de la superficie de muestras de madera de 'hornbeam' lijadas se midieron con un equipo llamado medidor de perfiles de contacto "Contact stylus profilmeter" PGK. Las características de la superficie de las muestras medidas fueron: rugosidad promedio (Ra), altura promedio cresta a valle (Rz), desviación media de los cuadrados medios de la rugosidad (Rq), profundidad de la rugosidad del núcleo (Rk), altura de la cresta reducida $(\mathrm{Rpk})$ y profundidad del valle reducida (Rvk). Se encontraron diferencias estadísticas significativas entre los índices de altitud para la variable profundidad de valle reducida y para la densidad de la madera secada en estufa, pero no para el resto de las variables. Esta variable no tuvo un efecto significativo en los parámetros de rugosidad de la madera de 'hornbeam'. La madera de altitudes bajas tuvo una superficie más rugosa que las altitudes intermedia y alta. No hay relación entre la rugosidad y la densidad de la madera secada en estufa.

Palabras ClaVe: condición de crecimiento, lijado, calidad de la superficie, madera aserrada, densidad de la madera.

\section{INTRODUCTION}

The genus Carpinus, from Betulaceae, comprises approximately 35 woody species around the world. It is widely found in Europe, eastern Asia, northern and Central America and China (Alden, 1997). In Iran, hornbeam (Carpinus betulus) covers about 33\% of commercial volume of Hyrcaniyan forest and is a native, diffuseporous hardwood species (Abdi et al., 2009). It is classified as a medium density hardwood, high in volumetric shrinkage and low in cleavage strength. Hornbeam, with its superior technological properties and high usage potential, is an important species in the lumber industry. Mostly, it is used for tool handles, levers, fuel wood, furniture and paper-making. Hornbeam has the maximum fiber length among Iranian hardwood species (Kiaei, 2012). 
Surface roughness strongly and directly affects the usages of wood products. The surface roughness is vital in production processes related to adhesive bonding and gluing of wood elements and final processing of finished products (Tan et al., 2012).

Roughness characterizes the fine irregularities on a machined surface of the wood. These irregularities can be determined by measuring the height, width and shape of the peaks and valleys produced by woodworking operations or by anatomical structural properties. The surface quality is a complex definition and it is characterized today by different parameters such as the more common Ra, Rz and Rmax parameters. Further details can be established using the Abbottcurve and its related parameters Rpk, Rk and Rvk (Fujiwara et al., 2003; Fujiwara et al., 2005).

The surface quality depends on wood properties and machining conditions. For the wood properties, the wood species, wood density, moisture content and the structural properties are more important. The structural properties are the annual ring width, latewood/earlywood ratio, specific number and distribution of inside diameter of tracheids and vessels (Theoma et al., 2015; Gurau, 2014).

The machining process has also a significant influence on the surface roughness. The most effective factors are the cutting velocity and the dullness of knives, the knife cutting angle to the grains and the vibration amplitude of machine table and workpiece (Kilic et al., 2006; Gurau, 2004; Gurau et al., 2005).

This study aimed to examine the surface roughness of hornbeam wood taken from various altitudes to investigate the relationship between wood density and surface roughness parameters.

\section{MATERIALS AND METHODS}

Six hornbeam trees with no obvious defects were selected from Mazandaran province, North of Iran. The trees were taken at three different elevations, namely $400 \mathrm{~m}$ above sea level (low elevation), $800 \mathrm{~m}$ (medium elevation) and $1200 \mathrm{~m}$ (high elevation). In January 2014, all six trees (two trees at each elevation) were randomly cut and transferred to the laboratory. All trees were at the same age range (45-50 years old), close range of height $(18 \mathrm{~m}-20 \mathrm{~m})$ and same class diameter at breast height $(30 \mathrm{~cm}-35 \mathrm{~cm})$. The annual temperature and annual rainfall in all of altitude classes were varied between $8{ }^{\circ} \mathrm{C}-14{ }^{\circ} \mathrm{C}$ and 1300 $\mathrm{mm} /$ year - $1350 \mathrm{~mm} /$ year, respectively.

The boards were taken from mature wood (near to bark). The age demarcation point between juvenile and mature wood was estimated at round 25 years (Clark and Saucier, 1989). The boards was first air dried to $30 \%-35 \%$ moisture content before drying in a laboratory type kiln to $12 \%$ of target moisture content. Dried board was cut to specimens with dimensions of $300 \mathrm{~mm} \times$ $300 \mathrm{~mm} \times 30 \mathrm{~mm}$ (radial, tangential, transverse) with tangential orientations for the surface roughness measurements. Surface of test pieces were sanded with sandpaper P80. Totally, 21 specimens (seven specimens $\times$ three altitudes) were selected to examine roughness parameters.

Measurements of surface roughness were done with a Contact stylus profilmeter PGK (Mehr Company, Germany) according to ISO-4287 (International Organization for Standardization [ISO], 1998b) and IS0-13565-2 (ISO, 1998a). The measured parameters were: average roughness $(\mathrm{Ra})$, mean peak-to-valley height $(\mathrm{Rz})$, root-mean square deviation of the profile $(\mathrm{Rq})$, core roughness depth $(\mathrm{Rk})$, reduced peak height (Rpk) and reduced valley depth (Rvk). The Ra, Rz and Rq are the most commonly used parameters in stylus method. In addition to these two parameters, Rk family parameters were also used to achieve more detailed information about the surfaces of machined specimens. The $\mathrm{Ra}, \mathrm{Rz}$ and $\mathrm{Rq}$ parameters are discussed in the previous studies (Hiziroglu, 1996; Mummery, 1993). However, description of Rk, Rvk, and Rpk are illustrated in figure 2 (Kilic et al., 2006; Mummery, 1993; Tan et al., 2012).

To determine wood oven-dried density (WD), a total of 60 specimens were selected (at breast height and specimens of mature wood), 20 from each different altitude. The measurement was based on ISO 3131 (ISO, 1975) standard. The wood density was measured based on the air-dry weight on the corresponding volumes. The air-dry volumes were calculated according the displacement method.

\section{Statistical analyses}

Duncan's post hoc test (Duncan multiple range test) at the probability level of $95 \%$ ( $p>0.05)$ was used to detect differences 
between the variables at different altitudes. The skewness and Shapiro-Wilk tests were performed for normality of collective data. Pearson's correlation coefficients between altituderoughness features were also determined to show their relationships. Linear regression equations were formulated to predict the relationship between surface roughness and wood density.

\section{RESULTS}

The results of analysis of variance (ANOVA) of roughness parameters are shown in table 1 . The results of the measurements of the roughness parameters are shown in table 2 . The values in the table 2 are average values of the surface roughness parameters and their standard deviation measured for hornbeam wood in three different altitude classes. Several measurements were done at different points of the wood surface and averaged.
The ANOVA results indicated that significant differences among all types of altitude indices were found for WD. The highest and lowest WD found in low and intermediate altitudes.

The results showed that the altitude index had no significant difference by the Ra parameter $(\mathrm{p}>0.05)$. The highest and lowest means of Ra were found in low (400 m) and intermediate altitudes $(800 \mathrm{~m})$, respectively. At the same sanding conditions, intermediate altitude had smoother surface roughness than others. There was a weak positive relationship between $\mathrm{Ra}$ and WD $\left(\mathrm{R}^{2}=0.140\right)$ in hornbeam wood (Fig. 1).

The results showed no significant difference between the altitude index and the Rq parameter at a 95\% confidence level. The highest and lowest means for Rq were found in low (400 m) and intermediate altitude $(800 \mathrm{~m})$, respectively. At the same sanding conditions, intermediate altitude had smoother surface roughness than other altitudes. A weak positive relationship

TABLE 1. ANOVA results of roughness parameter and WD in three different altitudes.

\begin{tabular}{cccccc}
\hline Properties & Sum of squares & $d f$ & Mean square & $F$ & Sig \\
\hline WD & 0.030 & 2 & 0.015 & 23.405 & 0.001 \\
Ra & 0.809 & 2 & 0.405 & 0.593 & 0.563 \\
Rz & 2.532 & 2 & 1.266 & 0.087 & 0.977 \\
Rq & 2.622 & 2 & 1.311 & 1.878 & 0.182 \\
Rk & 26.264 & 2 & 13.132 & 0.865 & 0.438 \\
Rpk & 9.420 & 2 & 4.710 & 1.669 & 0.216 \\
Rvk & 98.423 & 2 & 49.211 & 4.008 & 0.036 \\
\hline
\end{tabular}

Wood density (WD); average roughness (Ra), mean peak-to-valley height (Rz), root-mean square deviation of the profile (Rq), core roughness depth (Rk), reduced peak height (Rpk), and reduced valley depth (Rvk).

TABLE 2. The mean and standard deviation of surface roughness parameters in three different altitude classes for hornbeam wood.

\begin{tabular}{ccccc}
\hline Features & \multicolumn{4}{c}{ Altitude classes $(\mathrm{m})$} \\
& 400 & 800 & 1200 & Average \\
\hline WD $\left(\mathrm{kg} / \mathrm{m}^{3}\right)$ & $721(26)^{\mathrm{c}}$ & $628(30)^{\mathrm{a}}$ & $681(18)^{\mathrm{b}}$ & 676 \\
$\operatorname{Ra}(\mu \mathrm{m})$ & $5.132(0.536)$ & $4.651(0.971)$ & $4.906(0.903)$ & 4.896 \\
$\operatorname{Rz}(\mu \mathrm{m})$ & $27.680(3.138)$ & $27.673(4.542)$ & $26.940(3.663)$ & 27.431 \\
$\operatorname{Rq}(\mu \mathrm{m})$ & $7.069(0.677)$ & $6.279(0.866)$ & $6.368(0.940)$ & 6.572 \\
$\operatorname{Rk}(\mu \mathrm{m})$ & $12.026(4.087)$ & $14.417(3.041)$ & $14.380(4.426)$ & 13.608 \\
$\operatorname{Rpk}(\mu \mathrm{m})$ & $7.179(1.382)$ & $5.718(1.826)$ & $5.802(1.793)$ & 6.233 \\
$\operatorname{Rvk}(\mu \mathrm{m})$ & $13.840(4.980)^{\mathrm{b}}$ & $9.271(1.902)^{\mathrm{a}}$ & $9.225(2.899)^{\mathrm{a}}$ & 10.779 \\
\hline
\end{tabular}




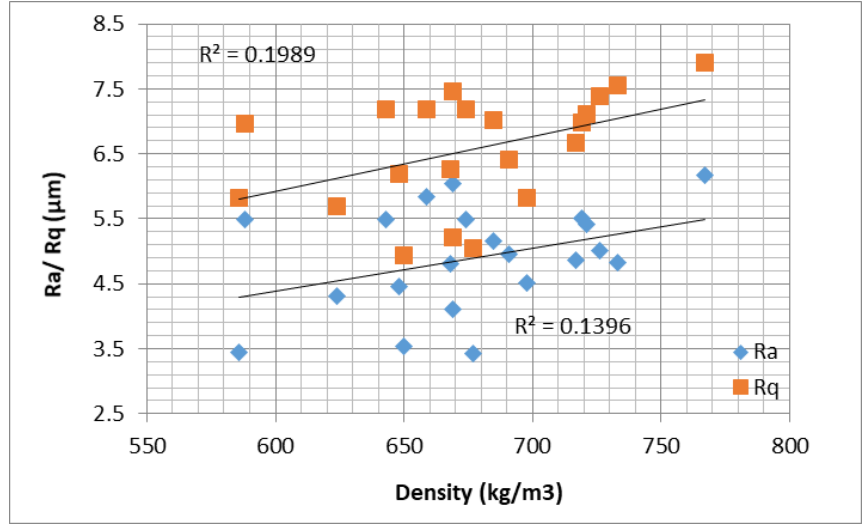

FIGURE 1. The relationship between WD with $\mathrm{Ra}$ and $\mathrm{Rq}$ in hornbeam species.

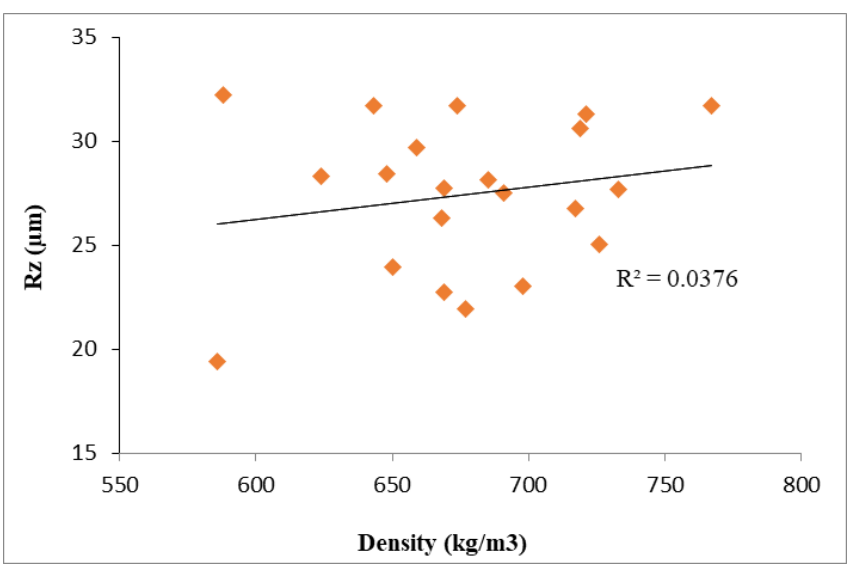

FIGURE 2. The relationship between WD and Rz in hornbeam species

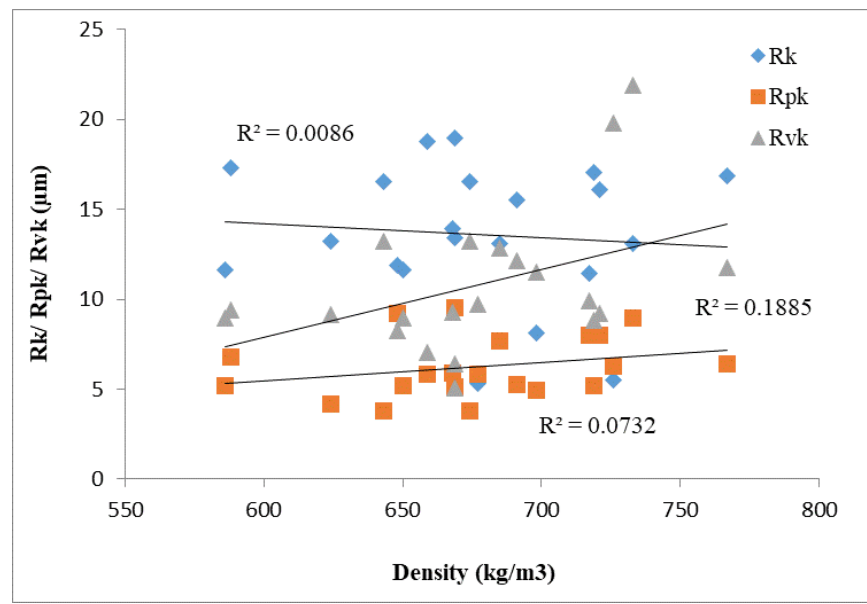

FIGURE 3. The relationship between WD and Rk, Rvk and Rpk in hornbeam species between Rq parameter and WD $\left(\mathrm{R}^{2}=0.199\right)$ in hornbeam wood was determined (Fig. 1).

Related to $\mathrm{Rz}$ parameter, no significant difference was observed by the altitude index $(\mathrm{P}>0.05)$. The $\mathrm{Rz}$ value was decreased by increasing the altitude indices. At the same treatment conditions, the specimens in high altitude were smoother than others. There was a weakly positive relationship between $\mathrm{Rz}$ parameter and WD $\left(\mathrm{R}^{2}=0.038\right)$ in hornbeam wood (Fig. 2).

Concerning to $\mathrm{Rk}$ parameter, there were no significant differences between them on different levels of altitudes at $95 \%$ confidence level. At the same sanding conditions, low altitude had smoother surface roughness than other altitudes. There was a weak and negative relationship between $\mathrm{Rk}$ parameter and WD $\left(\mathrm{R}^{2}=-0.009\right)$ in hornbeam wood (Fig. 3).

The statistical analysis revealed no significant difference on the Rpk parameter at different levels of altitudes $(\mathrm{p}>0.05)$. At the same sanding conditions, intermediate altitude had smoother surface roughness than other altitudes. There was a weak (positive) relationship between Rpk parameter and WD $\left(\mathrm{R}^{2}=\right.$ 0.073) in hornbeam wood (Fig. 3).

The ANOVA results indicated that significant differences were found among all classes of altitude indices for Rvk at a 95\% confidence level. The Duncan's mean separation test showed that a significant difference in the Rvk between low and high and between low and intermediate altitudes. Rvk value was decreased by increasing the altitude indices. At the same sanding conditions, high altitude had smoother surface roughness than other altitudes. There was weakly (positive) relationship between Rvk parameter and WD $\left(\mathrm{R}^{2}=0.189\right)$ for hornbeam wood (Fig. 3).

\section{DISCUSSION}

Some of researchers have stated that the surface roughness improved (low surface roughness) with increasing WD value (Lavery et al., 1995; Theoma et al., 2015). This statement is in disagreement with our results. There was no relationship between WD and surface roughness according to the linear regression coefficients in this study. Overall, the WD of hornbeam trees growing in low altitude $\left(721 \mathrm{~kg} / \mathrm{m}^{3}\right)$ is higher than other altitudes $\left(628 \mathrm{~kg} / \mathrm{m}^{3}\right.$ in intermediate altitude and $681 \mathrm{~kg} / \mathrm{m}^{3}$ in high 
altitude) and it has a higher surface roughness parameter (rougher surface) than other altitude.

The mean $\mathrm{Ra}$ parameter of hornbeam wood growing in three different altitudes was $4.896 \mu \mathrm{m}$. This value is higher than five Turkish species (beech, oak, walnut, Aleppo pine, white fir) and Albanian beech wood (Table 3). The mean Ra parameter for mentioned species was respectively determined $2.89 \mu \mathrm{m}, 4.62 \mu \mathrm{m}$, $3.97 \mu \mathrm{m}, 4.25 \mu \mathrm{m}, 3.32 \mu \mathrm{m}$ and $4.63 \mu \mathrm{m}$ (Thoma et al., 2015; Kilic et al., 2006). Thoma et al. (2015) founded that beech species has a smoother surface roughness than oak. The same can be said for the white fir, which has a smoother surface roughness than the Aleppo pine.

These differences of roughness parameters among species can to relate to both factors include structural characteristics and grit size of tested species (Table 3). The softwood tested species are classified in gradual transition earlywood/latewood (white fir) and abrupt transition (Aleppo pine), while the hardwood tested species are classified according wood porosity: diffuse porous (beech, hornbeam), semi-ring porous (walnut) and ring porous (oak). Also, the surface of beech, oak, walnut, fir and pine species were sanded by 120 grit size, while we used from 80 grit size for hornbeam species in the present study. Therefore, grit size of sandpaper can to effect on the surface roughness. We know that the roughness of the specimens significantly improved with increasing grit size of sandpaper (Carrano et al., 2002; Fujiwara et al., 2005; Gurau et al., 2007; Hendarto et al., 2006; Taylor et al., 1999).

The mean $\mathrm{Rz}$ parameter of hornbeam wood growing in three different altitudes was $27.341 \mu \mathrm{m}$. This value is higher than beech species and is lower than the oak, walnut, Aleppo pine and white fir (Table 3). It can be said the hornbeam wood has a smoother Rz parameter than semi-ring porous (walnut), ring porous (oak) and softwood species (white fir and Aleppo pine).

The mean $\mathrm{Rq}$ parameter of hornbeam wood growing in three different altitudes was $6.572 \mu \mathrm{m}$. This value in hornbeam wood is higher than all of the mentioned species. In other hand, the beech wood has a smoother surface (according to the results of Rq) than other species (Table 3).

The average $\mathrm{Rk}$ of hornbeam wood growing in three different altitudes was $13.608 \mu \mathrm{m}$, which is in the expected range of beech species. According to results of Rpk and Rvk, the Iranian hornbeam wood $(\operatorname{Rvk}=6.223 \mu \mathrm{m} ; \mathrm{Rpk}=10.779 \mu \mathrm{m})$ has a rougher surface than Albanian beech wood $(\operatorname{Rvk}=4.69 \mu \mathrm{m}$; $\mathrm{Rpk}=7.34 \mu \mathrm{m})$.

TABLE 3. Roughness parameters of various hardwood and softwood species.

\begin{tabular}{|c|c|c|c|c|c|c|c|}
\hline Species & Hornbeam & beech & oak & walnut & Aleppo pine & White fir & beech \\
\hline $\mathrm{Rz}(\mu \mathrm{m})$ & 27.431 & 20.55 & 37.84 & 31.39 & 36.20 & 29.54 & - \\
\hline $\mathrm{Rq}(\mu \mathrm{m})$ & 6.572 & 3.88 & 6.03 & 5.38 & 5.51 & 4.10 & - \\
\hline $\mathrm{Rk}(\mu \mathrm{m})$ & 13.608 & - & - & - & - & - & 13.96 \\
\hline $\operatorname{Rpk}(\mu \mathrm{m})$ & 10.779 & - & - & - & - & - & 7.34 \\
\hline Sample site & Iran & Turkey & Turkey & Turkey & Turkey & Turkey & Albania \\
\hline Grit size & 80 & 120 & 120 & 120 & 120 & 120 & 80 \\
\hline Load surface & Tangential & Tangential & Tangential & Tangential & Tangential & Tangential & Tangential \\
\hline
\end{tabular}

HW: hardwood; SW: softwood; DP: diffuse porous; RP: ring porous; SP: semi-ring porous; AT: abrupt transition; GT: gradual transition. 


\section{CONCLUSIONS}

In this study, the surface roughness of hornbeam wood in three different altitudes were determined, and these results were compared other wood species in different regions in world. The following conclusions were obtained from this research:

1. There is a significant difference among all of altitude indexes in WD. The value of wood density was decreased by increasing altitude classes from $400 \mathrm{~m}$ to $1200 \mathrm{~m}$. This difference can to attribute the variation of site (region), climate condition (rainfall, temperature, humidity) and region ecological condition.

2. Altitude index did not present a significant difference on Ra, $\mathrm{Rz}, \mathrm{Rq}, \mathrm{Rpk}$ and Rk parameters, while it had a significant effect on the Rvk parameter. There is not significant difference between intermediate altitude and high altitude is Rvk according to the results of Duncan's table.

3. Increasing the altitude classes from $400 \mathrm{~m}$ to $1200 \mathrm{~m}$ decreased the values of $\mathrm{Ra}, \mathrm{Rz}, \mathrm{Rq}, \mathrm{Rpk}$ and Rvk surface roughness parameters by $4.40 \%, 2.67 \%, 9.92 \%, 19.18 \%$ and $33.34 \%$, respectively; the $\mathrm{Rk}$ parameter increased by $19.57 \%$. There was no relationship between WD and surface roughness parameters according to the linear regression models in this study.

4. Hornbeam wood growing at intermediate $(800 \mathrm{~m})$ and high altitude $(1200 \mathrm{~m})$ has smoother surface roughness than low altitude $(400 \mathrm{~m})$ for wood production. Beech and hornbeam species are classified in hardwood species (diffuse porous), but beech wood has a smoother surface roughness than the studied species.

\section{REFERENCES}

Abdi, E., Majnounian, B., Rahimi, H., \& Zobeiri, M. (2009). Distribution and tensile strength of Hornbeam (Carpinus betulus) roots growing on slopes of Caspian Forests, Iran. Journal Forest Research, 20(2), 105-110. doi: 10.1007/s11676-009-0019-x

Alden, H. A. (1997). Softwoods of North America. General technical report FPLGTR-102. Madison, United States. U.S. Department of Agriculture, Forest Service, Forest Product Laboratory.Carrano, A. L., Taylor, J. B., \& Lemaster, R. (2002) Parametric characterization of peripheral sanding. Forest Products Journal, 52(9), 44-50.
Clark, A., \& Saucier, J. R. (1989) Influence of initial planting density, geographic location and species on juvenile wood formation in southern pine. Forest Products Journal, 39, 42-48.

Fujiwara, Y., Fujii, Y., \& Okumura, S. (2003) Effect of removal of deep valleys on the evaluation of machined surfaces of wood. Forest Products Journal, 53(2), 58-62.

Fujiwara, Y., Fujii, Y., \& Okumura, S. (2005). Relationship between roughness parameters based on material ration curve and tactile roughness for sanded surfaces of two hardwoods. Journal of Wood Science, $51(3), 274-277$.

Gurau, L. (2014). The influence of earlywood and latewood upon the processing roughness parameters at sanding. Proligno, 10(3), 2633.

Gurau, L. (2004). The roughness of sanded wood surfaces (doctoral thesis). Brunel University, High Wycombe, England.

Gurau, L., Mansfield-Williams, H., \& Irle, M. (2007) Separation of processing roughness from anatomical irregularities and fuzziness to evaluate the effect of grit size on sanded European oak. Forest Products Journal, 57(1/2), 110-115.

Gurau, L., Mansfield-Williams, H., \& Irle, M. (2005) Processing roughness of sanded wood surfaces. Holz als Roh - und Werkstoff, 63, 43-52.Hendarto, B., Shayan, E., Ozarska, B., \& Carr, R. (2006) Analysis of roughness of a sanded wood surface. International Journal of Advanced Manufacturing Technology, 28(7-8), 775-780.

Hiziroglu, S. (1996). Surface roughness analysis of wood composites: a stylus method. Forest Products Journal, 46(7/8), 67-72.

International Organization for Standardization [ISO] (1998a). ISO 13565-2 Geometrical product specification (GPS) - Surface texture: profile method; surface having stratified functional properties - Part 2: Height characterization using linear material ratio curve. London, England: British Standards Institute.

International Organization for Standardization [ISO] (1998b) ISO 4287 Geometrical product specification (GPS) surface texture: profile method-terms definitions and surface texture parameters. London, England: British Standards Institute.

International Organization for Standardization [ISO] (1996). ISO 3131 Wood - Determination of density for physical and mechanical tests. London, England: British Standards Institute.

Kiaei, M. (2012). Effect of site and elevation on wood density and shrinkage and their relationships in Carpinus betulus. Forest studied in China, 14(3), 229-234.Kilic, M., Hiziroglu, S., \& Burdurlu, E. 
(2006). Effect of machining on surface roughness of wood.

Building and Environment, 41, 1074-1078

Lavery, D. J., Mclarnontul, D., Taylor, J. M., Moloney, S., \& Atanackovic, A. (1995). Parameters affecting the surface finish of planed sitka spruce. Forest Products Journal, 45: 45-50.

Mummery, L. (1993). Surface texture analysis. The handbook. Muhlhausen, Germany: Hommelwerke.

Tan, P. L., Sharif, S., \& Sudin, I. (2012). Roughness models for sanded wood surfaces. Wood Science and Technology, 46, 129-142.

Taylor, J. B., Carrano, A. L., \& Lemaster, R. L. (1999). Quantification of process parameters in a wood sanding operation. Forest Products Journal, 9(5), 41-46.

Thoma, H., Peri, L., \& Lao, E. (2015). Evaluation of wood surface roughness depending on species charactertics. Maderas Ciencia y Tecnología, 17(2), 285-292.
Received: 23 June 2016

Accepted: 18 May 2017

Published: 23 March 2018

This paper must be cited as:

Kiaei, M., \& Mosavi P., R. (2018). Surface roughness in relation to altitude of hornbeam wood. Madera y Bosques, 24(1), e241964. doi: $10.21829 /$ myb.2018.241964

Madera y Bosques por Instituto de Ecología, A.C. se distribuye bajo una Licencia Creative Commons Atribución-NoComercialCompartirlgual 4.0 Internacional. 